Klinička psihologija 10 (2017), 1-2, 5-21

Izvorni znanstveni rad - UDK 159.922.76

DOI: $10.21465 / 2017-K P-1-2-0001$

\title{
RAZVOJNI PROFILI DJECE S POREMEĆAJEM IZ SPEKTRA AUTIZMA
}

\author{
Ana Šimir \\ Poliklinika za rehabilitaciju slušanja i govora SUVAG \\ Ljudevita Posavskog 10, 10000 Zagreb \\ anaa.simir@gmail.com \\ Sanja Šimleša \\ Laboratorij za istraživanje dječje komunikacije, \\ Odsjek za logopediju, Edukacijsko-rehabilitacijski fakultet, Sveučilište u Zagrebu \\ Borongajska cesta 83f, 10000 Zagreb \\ s.simlesa@gmail.com \\ Maja Cepanec \\ Laboratorij za istraživanje dječje komunikacije, Odsjek za logopediju, \\ Edukacijsko-rehabilitacijski fakultet, Sveučilište u Zagrebu \\ Borongajska cesta 83f, 10000 Zagreb \\ maja.cepanec@erf.hr
}

\begin{abstract}
Sažetak
Istraživanja pokazuju kako su neujednačeni razvojni profili, s boljim neverbalnim u odnosu na verbalne sposobnosti, karakteristika djece s poremećajem iz spektra autizma (PSA). Cilj ovog istraživanja bio je prikaz razvojnih profila djece sa PSA-om na Razvojnom testu Čuturić (RTČ-P), opis njihovih specifičnosti s obzirom na sveukupne intelektualne sposobnosti te razlika između različitih razvojnih područja. Uzorak je činilo 25 djece kod koje je utvrđen PSA. Razvojni profili su oblikovani obzirom na postignuća na zadacima RTČ-P-a. U skladu s očekivanjem, djeca sa PSA-om pokazala su neujednačene razvojne profile. Neujednačenost razvojnih područja je uočena i kod djece s prosječnim $(n=6)$ i kod djece $\mathrm{s}$ ispodprosječnim intelektualnim sposobnostima $(\mathrm{n}=19)$. U skladu s pretpostavkom i stranim istraživanjima, prosječna postignuća na neverbalnim sposobnostima pokazala su se boljima od onih na verbalnim sposobnostima. Pritom se kao područje s najboljim rezultatima ističu vizuoperceptivne sposobnosti. Ako sagledamo verbalne sposobnosti, pokazalo se kako je jezična proizvodnja nešto bolja u odnosu na razumijevanje, što je u skladu s pretpostavkom o smjeru neujednačenosti jezičnih sposobnosti. Zaključno, razvojni profili dobar su način isticanja djetetovih jakih i slabih strana, što je važno kod oblikovanja intervencije. Oni također mogu biti korisni u diferencijalnoj dijagnostici PSA-a i drugih razvojnih teškoća.
\end{abstract}

Ključne riječi: poremećaj iz spektra autizma, razvojni profili, Razvojni test Čuturić 


\section{UVOD}

Poremećaj iz spektra autizma (PSA) je razvojni poremećaj koji obilježavaju odstupanja u socijalnoj komunikaciji i socijalnim interakcijama te prisutnost ograničenih, ponavljajućih ponašanja, interesa ili aktivnosti (Američka psihijatrijska udruga, 2014). Od najranije dobi, u djece sa PSA-om često je vidljiv disharmoničan razvojni profil koji je posljedica neujednačenog razvoja sposobnosti u različitim razvojnim područjima (Matson, Dempsey, LoVullo i Wilkins, 2008). Navedeni nerazmjer sposobnosti, odnosno tako specifičan kognitivni profil neki autori smatraju čak i jedinstvenim dijagnostičkim pokazateljem poremećaja iz spektra autizma (Barbaro i Dissanayake, 2012).

Analize profila sposobnosti mjerenih putem testova inteligencije ponajviše ističu nerazmjer vizualnih sposobnosti u odnosu na sveukupni kvocijent inteligencije (Mayes i Calhoun, 2003; Mayes i Calhoun, 2008). Vrlo često se posebno ističe "nadmoć" vizuokonstruktivnih sposobnosti (Dawson, Soulieres, Gernsbacher i Mottron, 2007; Happe i Frith, 2006; Joseph, Tager-Flusberg i Lord, 2002; Muth, Honekopp i Falter, 2014). S druge strane, grafomotoričke sposobnosti su najčešće ispodprosječne ili lošije u odnosu na ostale neverbalne sposobnosti, posebice u odnosu na vizualne sposobnosti (Mayes i Calhoun, 2003). Ako sagledamo verbalne sposobnosti, jezične teškoće su karakteristika osoba s PSA-om te su često prisutne u svim aspektima jezika (ASHA, 2012). Međutim, istraživanja jezičnih sposobnosti ove populacije često su proturječna zbog metodoloških razlika, ali i izrazite heterogenosti uzoraka. Ipak, izrazito veliki broj istraživanja pokazuje kako su bolja postignuća na zadacima jezične proizvodnje u odnosu na jezično razumijevanje karakteristika osoba s PSA-om (Barbaro i Dissanayake, 2012; Ellis Weismer, Lord i Esler, 2010; Hudry i sur., 2010; Kwok, Brown, Smyth i Cardy, 2015; Thurm, Lord, Lee i Newschaffer, 2007; Volden i sur., 2011). Naime, u djece urednog razvoja, ali i u djece s nekim drugim razvojnim teškoćama, profil je gotovo uvijek obrnut, tj. jezično razumijevanje je uvijek na višoj razini od jezične proizvodnje jer nije moguće funkcionalno koristiti riječi koje ne razumijemo (Hudry i sur., 2010). Atipični jezični profili bi stoga mogli biti korisni u prepoznavanju i diferencijalnoj dijagnostici PSA-a i drugih razvojnih poremećaja. Međutim, velik utjecaj na rezultate imaju mjerni instrumenti koji se razlikuju u zahtjevnosti i broju čestica koje ispituju jezičnu proizvodnju i razumijevanje. Pritom je važno uzeti u obzir i stereotipnu jezičnu proizvodnju koja je karakteristična za PSA i mogla bi biti jedan od razloga prividno boljih sposobnosti.

Heterogenost unutar skupine djece s PSA-om može proizlaziti i iz varijabilnosti njihova kvocijenta inteligencije (Munson i sur., 2008). Naime, prema podacima Centra za kontrolu i prevenciju bolesti, otprilike $31 \%$ djece i odraslih sa PSA-om ima intelektualne teškoće (IQ $\leq 70$ ), 23\% ima granične intelektualne sposobnosti (IQ = 71-85), dok ih 46\% ima prosječne ili iznadprosječne intelektualne sposobnosti (IQ > 85) (Centres for Disease Control and Prevention, 2014). Međutim, ko- 
gnitivne teškoće često nisu generalizirane kroz sva razvojna područja (Rommelse i sur., 2015). Naime, obilježja neujednačenih razvojnih profila prisutna su u djece sa PSA-om neovisno o sveukupnim intelektualnim sposobnostima, odnosno disharmonični razvojni profil je prisutan u djece sa PSA-om urednih intelektualnih sposobnosti i u djece koja, uz PSA, imaju i opće razvojno zaostajanje (rana dob) ili intelektualne teškoće (kasnija dob) (Mayes i Calhoun, 2003). Istraživanja koja su se bavila usklađenošću neverbalnih i verbalnih sposobnosti donijela su prilično različite rezultate. Tako Ankenman, Elgin, Sullivan, Vincent i Bernier (2014) navode brojna istraživanja s oprečnim rezultatima - neka pokazuju da djeca sa PSAom imaju bolje verbalne, a neka da imaju bolje neverbalne sposobnosti. Kao uzrok neslaganja vide različite dijagnostičke kriterije, veličinu uzoraka, dob sudionika istraživanja i sl. No, rezultati većine istraživanja ipak govore u prilog tezi da djeca sa PSA-om imaju, generalno, bolje razvijene neverbalne od verbalnih sposobnosti. Neki autori izraženiju neujednačenost u obliku boljih neverbalnih sposobnosti vežu uz nižu kronološku dob te smatraju da sazrijevanjem verbalne sposobnosti dostižu neverbalne, odnosno da tijekom razvoja profil postaje sve ujednačeniji (Ankenman i sur., 2014; Mayes i Calhoun, 2003; Munson i sur., 2008).

Strana istraživanja pružaju opširan uvid u atipičnost i neujednačenost razvojnih domena djece sa PSA-om. Porastom učestalosti PSA-a, te sve ranijom i sve kvalitetnijom dijagnostikom, porastao je i klinički i znanstveni interes za ovu populaciju u Hrvatskoj.

U Republici Hrvatskoj trenutačno se za procjenu općih kognitivnih sposobnosti djece rane i predškolske dobi najčešće koristi Razvojni test Čuturić (Čuturić, 1996). Iz ranijih navoda jasno je da uočena disharmonija u većoj mjeri može ovisiti o dobi sudionika, ali i o primijenjenom mjernom instrumentu. Dosad nisu provođena istraživanja koja bi pokazala obilježja razvojnog profila djece rane i predškolske dobi prema rezultatima Razvojnog testa Čuturić. Stoga je cilj ovog rada prikazati razvojne profile djece rane i predškolske dobi s PSA-om putem rezultata na Razvojnom testu Čuturić, te opisati njihove specifičnosti s obzirom na sveukupne intelektualne sposobnosti, kao i moguće razlike između različitih razvojnih područja. Postavlja se pitanje hoće li djeca kojoj je dijagnosticiran PSA kao grupa pokazati neujednačen razvojni profil, te hoće li sveukupne intelektualne sposobnosti imati utjecaj na razvojne profile, kao i u kojem smjeru postoje neujednačenosti među razvojnim područjima.

Sukladno rezultatima međunarodnih istraživanja, te navedenom cilju, oblikovane su sljedeće pretpostavke: (1) Djeca sa PSA-om će kao grupa pokazati neujednačene razvojne profile; (2) Djeca sa PSA-om će pokazati neujednačene razvojne profile, neovisno o sveukupnim intelektualnim sposobnostima; (3) Djeca sa PSA-om će postizati prosječno bolje rezultate u području neverbalnih sposobnosti, u odnosu na verbalne sposobnosti; (4) Djeca sa PSA-om će postizati prosječno bolje rezultate u području jezične proizvodnje, u odnosu na jezično razumijevanje. 


\section{METODE RADA}

\section{Sudionici istraživanja}

Prigodni uzorak činila su djeca kojoj je dijagnosticiran PSA tijekom razvojnih procjena u Kabinetu za ranu komunikaciju u Centru za rehabilitaciju Edukacijskorehabilitacijskog fakulteta u Zagrebu. U uzorak je uključeno 25 djece kod koje je primijenjen Razvojni test Čuturić za predškolsku dob (RTČ-P). Prosječna kronološka dob sudionika istraživanja bila je 4;09 godina $(\mathrm{SD}=1,269)$. Pritom je najmlađi sudionik imao 2;05 godina, a najstariji 6;11 godina.

\section{Mjerni instrument i postupak}

Razvojni test Čuturić (RTČ; Čuturić, 1996) sastoji se od dva dijela. Prvi dio (RTČ-M) ispituje psihički razvoj djece od 1. mjeseca do 2. godine, dok drugi dio (RTČ-P) ispituje psihički razvoj djece od 2. do 8. godine života. Svi sudionici ovog istraživanja $(n=25)$ ispitani su Razvojnim testom Čuturić za predškolsku dob (RTČ-P). RTČ-P se sastoji od 7 podljestvica (svaka za jednu godinu od 2. do 8 . godine života), a u svakoj podljestvici je 6 zadataka. Svi sudionici istraživanja su rješavali zadatke maksimalno do podljestvice za kronološku dob od 5 godina pa zadnje tri podljestvice nisu ni ulazile u analizu. Na svakoj podljestvici prvi zadatak ispituje rukovanje kockama, drugi sastavljanje predmeta, treći rukovanje olovkom, četvrti zadatak ispituje razvoj govora, a peti zadatak verbalno izražavanje znanja (Čuturić, 1996). Za potrebe ovog istraživanja prvi zadatak je nazvan vizuokonstruktivnim, drugi vizuoperceptivnim, treći grafomotoričkim, četvrti zadatkom jezične proizvodnje, a peti zadatkom jezičnog razumijevanja. Zbog obilježja suradnje djece sa PSA-om zadatak koji ispituje motoričke sposobnosti nije uzet u obzir jer nisu postojali podaci za sve sudionike. U skladu s tim, prva tri zadatka na svakoj podljestvici ispituju neverbalne sposobnosti, a zadnja dva verbalne sposobnosti.

Procjene su se provodile u prostoru Kabineta za ranu komunikaciju Centra za rehabilitaciju Edukacijsko-rehabilitacijskog fakulteta u Zagrebu. Svako dijete je ispitano individualno, uz prisutnost roditelja ili skrbnika.

\section{Statistička obrada podataka}

Prikupljeni podaci su uneseni i kodirani u Microsoft Excel programu te statistički obrađeni programom SPSS 20.0. Zbog načina bodovanja zadataka na RTČ-P-u, te varijable su kodirane kao ordinalne ljestvice. Od postignutih mentalnih dobi po pojedinim podljestvicama oduzeta je kronološka dob pojedinog djeteta. Na taj način 
su odstupanja prikazana u godinama, tako da negativan predznak označava koliko je testom izračunata mentalna dob niža od kronološke dobi. Nula, stoga, označava postignuće očekivano za kronološku dob, a pozitivan predznak označava koliko je testom izračunata mentalna dob viša od kronološke dobi na pojedinoj razvojnoj domeni. Osnovni statistički parametri su izračunati za sve varijable. Aritmetičke sredine rezultata na varijablama Vizuokonstruktivne sposobnosti, Vizuoperceptivne sposobnosti, Grafomotoričke sposobnosti, Jezična proizvodnja i Jezično razumijevanje prikazane su grafički.

\section{REZULTATI I RASPRAVA}

(Ne)ujednačenost sveukupnog razvojnog profila djece sa PSA-om

U Tablici 1 prikazana je deskriptivna statistika na ispitanim varijablama za sve sudionike istraživanja. Podaci pokazuju da postoje razlike među postignutim rezultatima na različitim varijablama ispitanim testom RTČ-P. Pritom se najviše ističe rezultat na varijabli Vizuoperceptivne sposobnosti, na kojoj sudionici postižu najviše rezultate. Naime, vidljivo je da su sudionici istraživanja upravo na toj varijabli prosječno postizali rezultate najbliže svojoj kronološkoj dobi. U ostalim sposobnostima, procijenjena mentalna dob je bila, na razini grupe, otprilike za dvije godine niža od kronološke dobi.

Aritmetičke sredine odstupanja prosječne mentalne dobi postignute na zadacima RTČ-P-a u odnosu na prosječnu kronološku dob izraženu u godinama prikazane su i grafički (Slika 1). Vizualno je veoma uočljivo kako su razvojni profili sudionika istraživanja neujednačeni. Time je potvrđena prva pretpostavka kako će djeca sa PSA-om kao grupa pokazati neujednačene razvojne profile. To je u skladu i s rezultatima stranih istraživanja (Ankenman i sur., 2014; Barbaro i Dissanayake, 2012; Chapman i sur., 2011; Matson i sur., 2008). Klinički je zapravo sasvim jasno

Tablica 1. Osnovni statistički parametri na ispitanim varijablama za sve sudionike istraživanja

\begin{tabular}{lccccc}
\hline Varijabla & $N$ & $X$ & $S D$ & MIN & MAX \\
\hline Vizuokonstruktivne sposobnosti & 25 & $-1,76$ & 1,363 & -4 & 2 \\
Vizuoperceptivne sposobnosti & 25 & $-0,44$ & 1,557 & -4 & 2 \\
Grafomotoričke sposobnosti & 25 & $-2,12$ & 1,301 & -5 & 1 \\
Jezična proizvodnja & 25 & $-1,96$ & 1,719 & -5 & 1 \\
Jezično razumijevanje & 25 & $-2,32$ & 1,180 & -5 & -1 \\
\hline
\end{tabular}




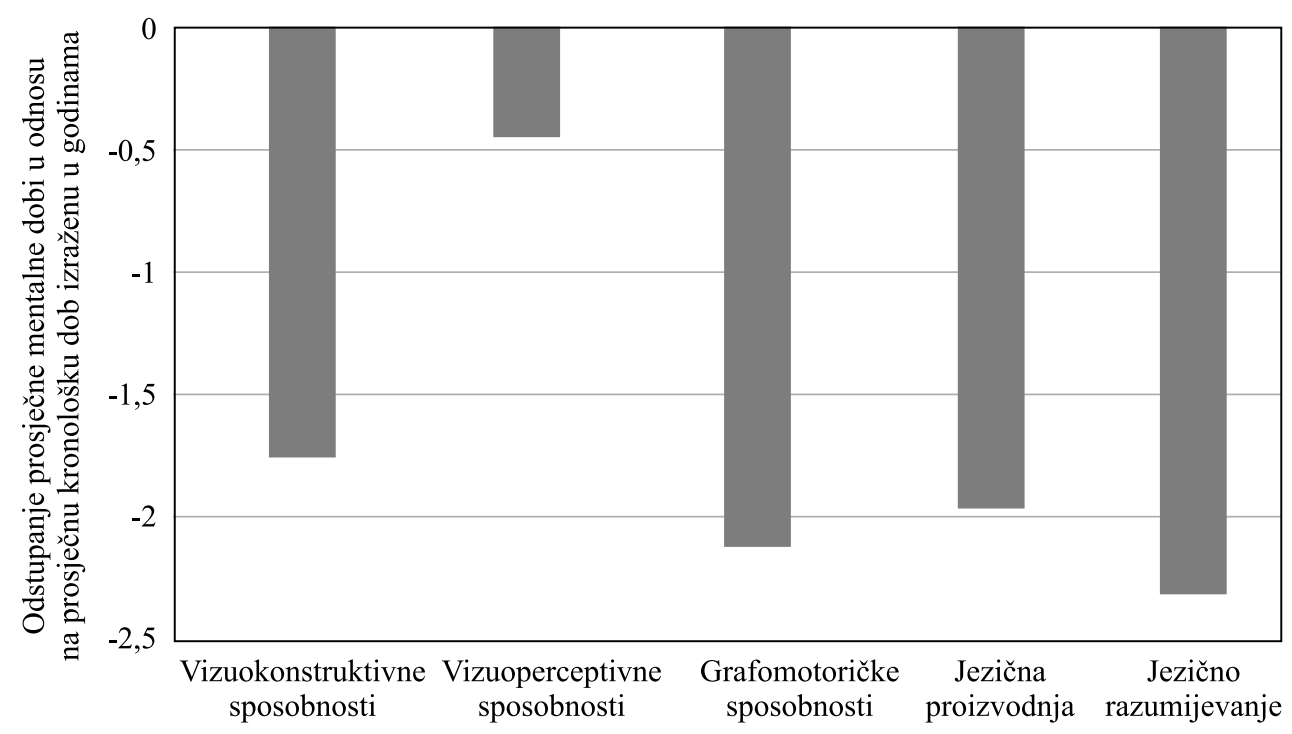

Slika 1. Prikaz razvojnih profila djece sa PSA-om $(\mathrm{n}=25)$ s obzirom na odstupanja prosječne mentalne dobi postignute na podljestvicama RTČ-P-a u odnosu na prosječnu kronološku dob izraženu u godinama

da profil, primjerice, četverogodišnjeg djeteta, u kojem disparitet među različitim razvojnim domenama iznosi dvije godine, upućuje na izrazitu razvojnu disharmoničnost.

Obilježja razvojnog profila u odnosu na opću razinu intelektualnih sposobnosti

U Tablici 2 prikazani su rezultati sudionika razdijeljeni s obzirom na sveukupne procijenjene intelektualne sposobnosti. Djeca su podijeljena u dvije skupine, djeca s ispodprosječnim intelektualnim sposobnostima i djeca s prosječnim intelektualnim sposobnostima, na temelju rezultata na RTČ-P ljestvici kao i na temelju priloženih kliničkih nalaza.

Uvidom $u$ aritmetičke sredine postignuća na ispitanim varijablama, vidljivo je kako su, očekivano, djeca s ispodprosječnim intelektualnim sposobnostima $(\mathrm{n}=19)$ prosječno postizala niže rezultate na svim varijablama u odnosu na djecu s prosječnim intelektualnim sposobnostima $(n=6)$. No, u obje su skupine uočljive razlike među postignućima na različitim varijablama (Tablica 2).

Usporedbom razvojnih profila djece s ispodprosječnim i prosječnim intelektualnim sposobnostima potvrdila se druga pretpostavka da će djeca sa PSA-om pokazati neujednačene razvojne profile neovisno o sveukupnim intelektualnim sposobnosti- 
Tablica 2. Osnovni statistički parametri na ispitanim varijablama s obzirom na sveukupne intelektualne sposobnosti

\begin{tabular}{|c|c|c|c|c|c|c|c|c|c|c|}
\hline \multirow[b]{3}{*}{ Varijabla } & \multicolumn{10}{|c|}{ Intelektualne sposobnosti } \\
\hline & \multicolumn{5}{|c|}{ Ispodprosječne } & \multicolumn{5}{|c|}{ Prosječne } \\
\hline & $N$ & $X$ & $S D$ & MIN & MAX & $N$ & $X$ & $S D$ & MIN & MAX \\
\hline $\begin{array}{l}\text { Vizuokonstruktivne } \\
\text { sposobnosti }\end{array}$ & 19 & $-2,26$ & 0,99 & -4 & -1 & 6 & $-0,17$ & 1,17 & -1 & 2 \\
\hline $\begin{array}{l}\text { Vizuoperceptivne } \\
\text { sposobnosti }\end{array}$ & 19 & $-0,95$ & 1,43 & -4 & 1 & 6 & 1,17 & 0,41 & 1 & 2 \\
\hline $\begin{array}{l}\text { Grafomotoričke } \\
\text { sposobnosti }\end{array}$ & 19 & $-2,42$ & 1,35 & -5 & 1 & 6 & $-1,17$ & 0,41 & -2 & -1 \\
\hline Jezična proizvodnja & 19 & $-2,53$ & 1,43 & -5 & 0 & 6 & $-0,17$ & 1,33 & -2 & 1 \\
\hline $\begin{array}{l}\text { Jezično } \\
\text { razumijevanje }\end{array}$ & 19 & $-2,68$ & 1,11 & -5 & -1 & 6 & $-1,17$ & 1,23 & -2 & -1 \\
\hline
\end{tabular}

ma. Vidljivo je da su profili neujednačeni za obje skupine, ali na različitim razvojnim razinama (Slika 2).

Pritom se u obje skupine i nadalje ističe varijabla Vizuoperceptivne sposobnosti, koja je ujedno i jedina varijabla na kojoj djeca s prosječnim intelektualnim sposobnostima postižu iznadprosječne rezultate, otprilike 1 godinu iznad svoje kronološke dobi. Veoma blizu svojoj kronološkoj dobi prosječno su postizali rezultate i na varijablama Vizuokonstruktivne sposobnosti i Jezična proizvodnja. Premda su rezultati na varijabli Jezična proizvodnja gotovo prosječni, a varijabla Jezično razumijevanje odstupa oko godinu dana od kronološke dobi (što upućuje na blagu atipičnost u razvojnom profilu), opravdano je pretpostaviti kako njihove komunikacijske teškoće uzrokuju značajnija odstupanja u nekim složenijim aspektima jezične proizvodnje koju test RTČ-P ne ispituje (npr. fleksibilnost jezične proizvodnje, izvještavanje, pragmatika i sl.). Posebno je važno naglasiti da zadaci varijable Jezična proizvodnja testa RTČ-P vrlo često ispituju one sadržaje koji se uvježbavaju na terapiji djece sa PSA-om (npr. imenovanje predmeta i brojenje do 10) s jedne strane, a da i gramatička ispravnost jezične proizvodnje u djece sa PSA-om može biti ,atipična“ na način da je odraz izgovaranja (gramatički ispravnih) upamćenih cjelina, što je čest slučaj kod djece sa PSA-om. Stoga možemo pretpostaviti da bi, da se ispituju drugi, složeniji aspekti jezične proizvodnje, odstupanja u verbalnom aspektu razvoja bila veća i kod djece s prosječnim intelektualnim sposobnostima.

Djeca $\mathrm{s}$ ispodprosječnim intelektualnim sposobnostima $(\mathrm{n}=19)$ postigla su gotovo identičan međuodnos vizuokonstruktivnih i vizuoperceptivnih sposobnosti kao i djeca bez intelektualnih teškoća, samo na nižoj razvojnoj razini. Na varijabli Vizuoperceptivne sposobnosti čak postižu rezultate veoma blizu svojoj prosječnoj 


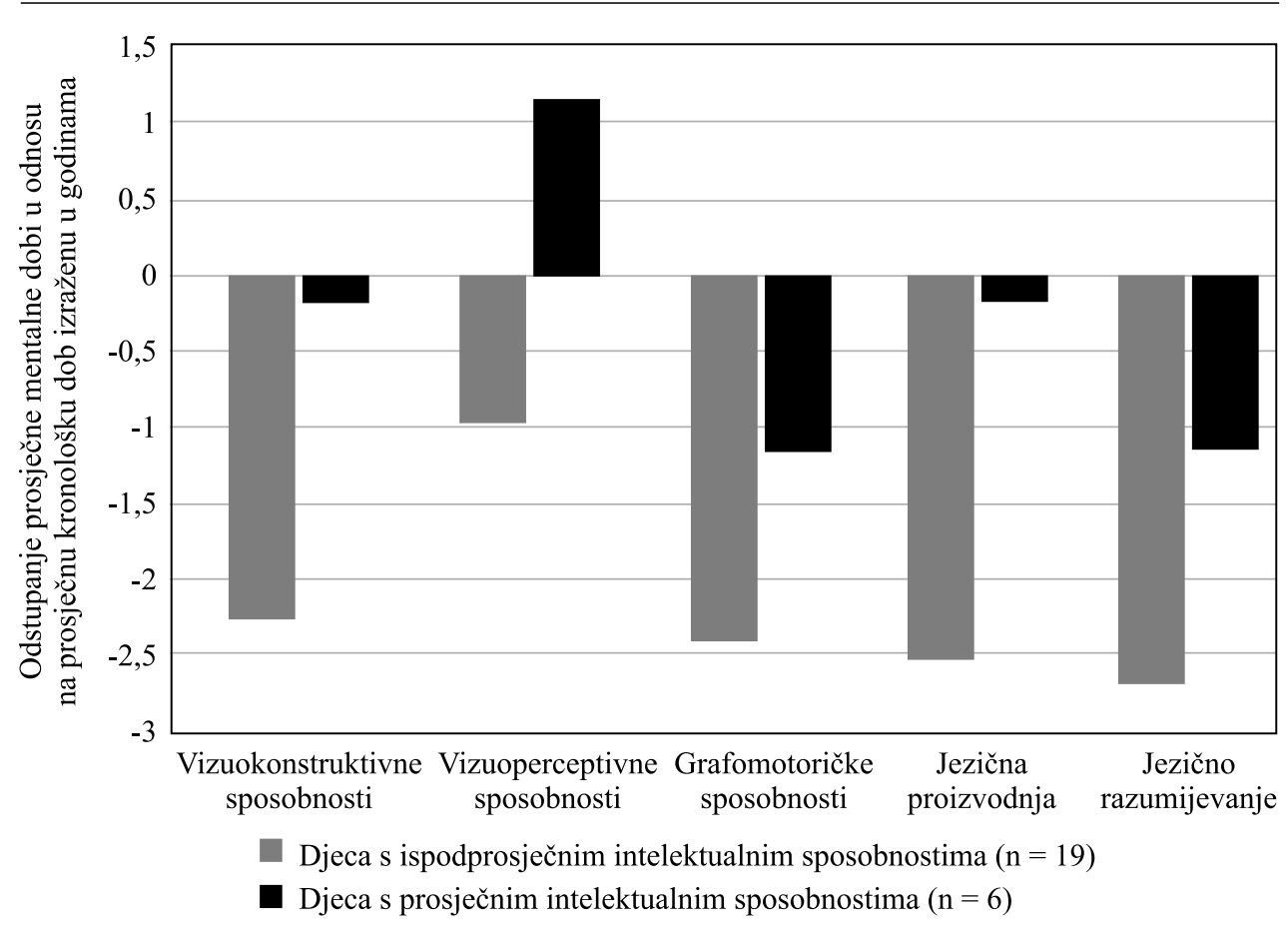

Slika 2. Prikaz razvojnih profila djece sa PSA-om s ispodprosječnim intelektualnim sposobnostima i s prosječnim intelektualnim sposobnostima s obzirom na odstupanja prosječne mentalne dobi postignute na podljestvicama RTČ-P-a u odnosu na prosječnu kronološku dob izraženu u godinama

kronološkoj dobi. Tako visoko postignuće, blizu prosječnog, bilo bi neobično kada bi se radilo o djeci s općim razvojnim zaostajanjem ili intelektualnim teškoćama bez dijagnoze PSA-a. Ovakav rezultat govori u prilog tome kako atipičnost percepcije i obrade utječe na kognitivni fenotip karakterističan za PSA (Caron, Mottron, Berthiaume i Dawson, 2006).

Analiza razvojnog profila po razvojnim područjima

Razmatrajući cjelokupni razvojni profil, vizuokonstruktivne i vizuoperceptivne sposobnosti ističu se kao područja s najvišim postignućima u odnosu na ostala razvojna područja. To nije neobično budući da su brojna istraživanja, kako je navedeno i u uvodnom dijelu ovog rada, pokazala da djeca sa PSA-om obično pokazuju bolje vizualne sposobnosti u odnosu na sveukupni kvocijent inteligencije (Mayes i Calhoun, 2003; Mayes i Calhoun, 2008). No, jedan podatak nije u potpunosti u skladu s očekivanjima, ako uzmemo u obzir rezultate većine drugih istraživanja. 
Naime, sudionici ovog istraživanja su, kao grupa, najviše rezultate postizali u području vizuoperceptivnih sposobnosti, dok se u literaturi često ističe kako su vizuokonstruktivne sposobnosti te koje su superiorne u odnosu na ostale (Happe i Frith, 2006; Joseph i sur., 2002; Muth i sur., 2014), pa čak i vizuoperceptivne sposobnosti (Dawson i sur., 2007). Međutim, treba imati na umu da se većina stranih istraživanja na ovom području zasniva na Wechslerovoj ljestvici inteligencije (Wechsler, 1991). Zadaci koji na toj ljestvici ispituju vizuokonstruktivne (Slaganje kocaka) i vizuoperceptivne sposobnosti (Sastavljanje predmeta) nemaju identičnu zahtjevnost i način provođenja kao zadaci na testu RTČ-P koji ispituju iste sposobnosti. Primjerice, vizuoperceptivni zadaci na testu RTČ-P u početku (za dob 2 i 3 godine) zahtijevaju samo stavljanje likova u ploču, a kasnije u dobi 4, 5 i 6 godina sastavljanje slike koja je manje zahtjevna od onih u Wechslerovoj ljestvici inteligencije. No, valja zamijetiti da su se vizuoperceptivni zadaci testa RTČ-P autoricama ovog rada općenito pokazali (pre)jednostavnima (za djecu određene kronološke dobi), te možda nemaju dovoljnu zahtjevnost da bi bili odraz stvarne razine vizuoperceptivnih sposobnosti kod djece općenito. Nadalje, i dobne razlike u stranim istraživanjima onemogućavaju direktno uspoređivanje. Primjerice, istraživanje Dawson i sur. (2007) koje je pokazalo izrazito bolje vizuokonstruktivne sposobnosti u odnosu na ostale sposobnosti, provedeno je na uzorku prosječne kronološke dobi 10 godina. Prosječna kronološka dob sudionika ovog istraživanja bila je 4;08 godina. Dobne razlike, odnosno sazrijevanje, mogle bi imati značajan utjecaj na postignuća na pojedinim razvojnim područjima, kao i u samim obilježjima razvojnog profila.

Uz Jezičnu proizvodnju i Jezično razumijevanje, kao područje s prosječno najnižim postignućima djece s PSA-om na RTČ-P-u pokazala se varijabla Grafomotoričke sposobnosti. Neki od sudionika ovog istraživanja nisu uopće uzimali olovku u ruke ili im je crtanje bilo na razini šaranja. Oni koji su surađivali na zadatku i pokušali imitirati ispitivača, često nisu uspijevali pravilno precrtati zadani geometrijski oblik, primjeren za kronološku dob pojedinog djeteta. Takvi rezultati su u skladu sa stranim istraživanjima koja govore o lošijim postignućima u području grafomotorike u odnosu na sveukupni kvocijent inteligencije (Mayes i Calhoun, 2003). Ispitivanjem grafomotorike dobiva se uvid u vizuomotornu integraciju ( $\mathrm{Zi}$ viani i Wallen, 2006), koja uključuje i vizualnu percepciju i motoričke sposobnosti (Kushki, Chau i Anagnostou, 2011). Budući da se vizualna percepcija pokazala kao jaka strana djece s PSA-om, moglo bi se zaključiti kako ta djeca imaju teškoća na motoričkom planu i/ ili integraciji vizualnih i motoričkih sposobnosti. Također, Kushki i sur. (2011) smatraju kako su teškoće u vizuomotornoj integraciji uočljive samo na zadacima koji uključuju papir i olovku, što je slučaj sa grafomotoričkim zadatkom u RTČ-P-u. No, lošiji rezultati na zadacima grafomotorike mogu biti posljedica i lošijih imitativnih sposobnosti i sposobnosti suradnje, budući da uspjeh na zadacima grafomotorike u većoj mjeri (nego što je uspjeh na zadacima vizualne percepcije ili vizualne konstrukcije) ovisi o suradnji s ispitivačem i imitaciji njegovih radnji. 


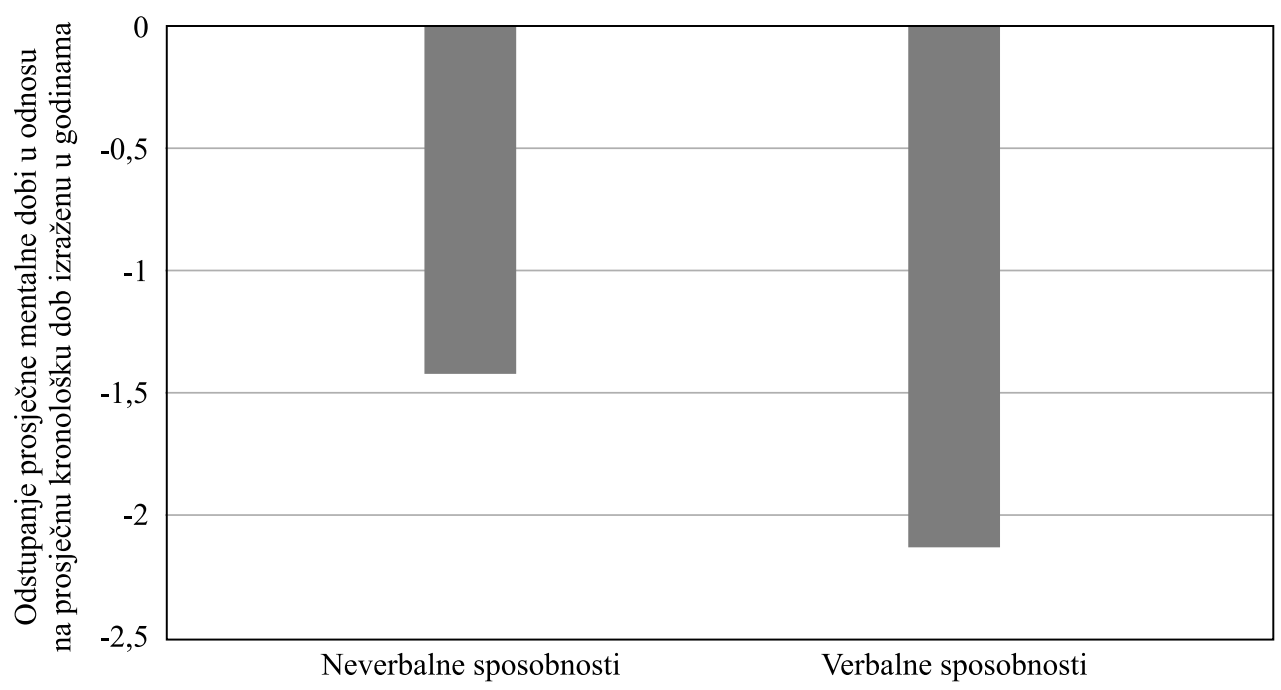

Slika 3. Prikaz razlika u neverbalnim i verbalnim sposobnostima djece sa PSA-om $(\mathrm{n}=25)$ s obzirom na odstupanja prosječne mentalne dobi postignute na podljestvicama RTČ-P-a u odnosu na prosječnu kronološku dob izraženu u godinama

Sukladno stranim istraživanjima (Ankenman i sur., 2014; Barbaro i Dissanayake, 2012), varijable Jezična proizvodnja i Jezično razumijevanje pokazale su se kao područja s prosječno najnižim postignućima u odnosu na ostala razvojna područja. Vidljivo je kako su prosječna postignuća na verbalnim sposobnostima (Jezična proizvodnja i Jezično razumijevanje) niža od prosječnih postignuća na neverbalnim sposobnostima (Vizuokonstruktivne sposobnosti, Vizuoperceptivne sposobnosti i Grafomotoričke sposobnosti), što potvrđuje treću pretpostavku (Slika 3). Upravo ovakav razvojni obrazac djece s PSA-om je najčešće i spominjan u literaturi (Ankenman i sur., 2014; Barbaro i Dissanayake, 2012; Joseph i sur., 2002; Munson i sur., 2008). Bilo bi relevantno istu djecu ispitati u školskoj dobi i provjeriti postoji li promjena odnosa verbalnih i neverbalnih sposobnosti, tj. dostižu li s vremenom verbalne sposobnosti neverbalne kao što sugeriraju neka strana istraživanja (Ankenman i sur., 2014; Joseph i sur., 2002; Munson i sur., 2008).

Lošija postignuća na verbalnim sposobnostima velikim dijelom proizlaze iz teškoća u socijalnoj kogniciji i socijalnoj komunikaciji, koje su jedne od glavnih karakteristika osoba sa PSA-om. Djeca često nisu bila socijalno odgovorljiva niti su na temelju uputa razumjela što se od njih očekuje na pojedinom zadatku, što je bitno za provođenje verbalnih zadataka. Motiviranost vizualno zanimljivim ispitnim materijalom za vizuokonstruktivne i vizuoperceptivne sposobnosti (kocke i slike), ali i osjećajem uspjeha na tim zadacima, rezultirala je i boljim rezultatima na tom području. Istraživanje Pierce, Marinero, Hazin, McKenna, Carter Banes i Malige 


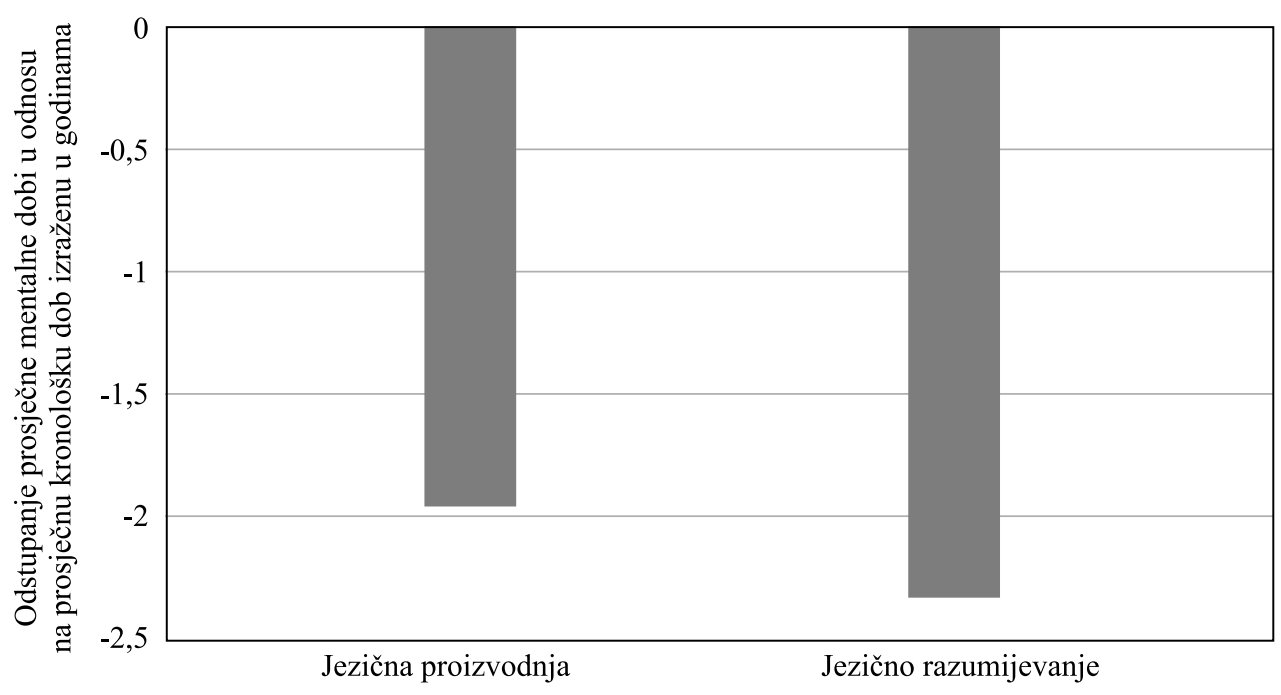

Slika 4. Prikaz razlika u sposobnostima jezične proizvodnje i razumijevanja djece sa PSAom $(n=25)$ s obzirom na odstupanja prosječne mentalne dobi postignute na podljestvicama RTČ-P-a u odnosu na prosječnu kronološku dob izraženu u godinama

(2016) pokazalo je kako djeca sa PSA-om u dobi između 12 i 49 mjeseci više preferiraju geometrijske oblike od slika koje prikazuju socijalne situacije. Dio vizuoperceptivnih zadataka na testu RTČ-P uključuje upravo usmjerenost na geometrijske oblike i njihovo povezivanje, dok većina verbalnih zadataka podrazumijeva usmjerenost na komunikacijskog partnera, odgovaranje na pitanja i izvršavanje naloga.

Usporedbom prosječnih postignuća na varijablama Jezična proizvodnja i Jezično razumijevanje, potvrđena je četvrta pretpostavka kako će jezična proizvodnja biti na višoj razini od razumijevanja (Slika 4).

Razlika između te dvije varijable nije velika, ali govori u prilog većini stranih istraživanja koja su pokazala kako su za PSA karakteristični atipični jezični profili koji se ne pojavljuju u urednom razvoju ni drugim razvojnim teškoćama. Takvi atipični jezični profili se odnose na bolja postignuća u jezičnoj proizvodnji, u odnosu na jezično razumijevanje (Barbaro i Dissanayake, 2012; Ellis Weismer i sur., 2010; Hudry i sur., 2010; Kwok i sur., 2015; Luyster, Kadlec, Carter i Tager-Flusberg, 2008; Thurm i sur., 2007; Volden i sur., 2011). Jedan od mogućih čimbenika koji je također mogao utjecati na smanjenu razliku između ove dvije sposobnosti su obilježja samih zadataka testa RTČ-P. Naime, jezično razumijevanje se ponekad ispituje na način da dijete mora dati verbalni odgovor, što nije karakteristično za jezične testove. U skladu s tim, važno je navesti da postoje i istraživanja koja su pokazala kako odnos jezičnog razumijevanja i proizvodnje djece sa PSA-om ovisi o mjernim instrumentima te koja sugeriraju da atipični jezični profili možda nisu nužno ka- 
rakteristika djece sa PSA-om, već razlike u mjernim instrumentima (Luyster i sur., 2008). Dakle, pri interpretaciji rezultata i usporedbi s drugim istraživanjima nužan je oprez zbog korištenja različitih mjernih instrumenata. Ponekad različite mjere pokazuju različita postignuća čak i unutar istog uzorka (Hudry i sur., 2013), a pri usporedbi istraživanja na umu treba imati i dobne razlike i sveukupne kognitivne sposobnosti.

Hudry i sur. (2010) napominju kako niskofunkcionirajuća (engl. low-functioning) djeca sa PSA-om pokazuju tipične jezične profile jer dijete koje, primjerice, razumije samo 10 riječi često ili uopće ne govori ili govori samo maksimalno tih 10 riječi. S druge strane, visokofunkcionirajuće (engl. high-functioning) dijete koje razumije puno više riječi, ali i ima jako dobro fonološko pamćenje, ima puno više mogućnosti za varijacije u proizvodnji te se u tom slučaju mogu pojaviti atipično bolje sposobnosti jezične proizvodnje. Pritom često proizvode upamćene rečenice i fraze koje zapravo ne razumiju. Također, istraživanje Kwok i sur. (2015) djece sa PSA-om dobi od 24 do 59 mjeseci pokazalo je kako su djeca s boljim neverbalnim sposobnostima, starije kronološke dobi i blažih simptoma pokazivala atipični jezič-

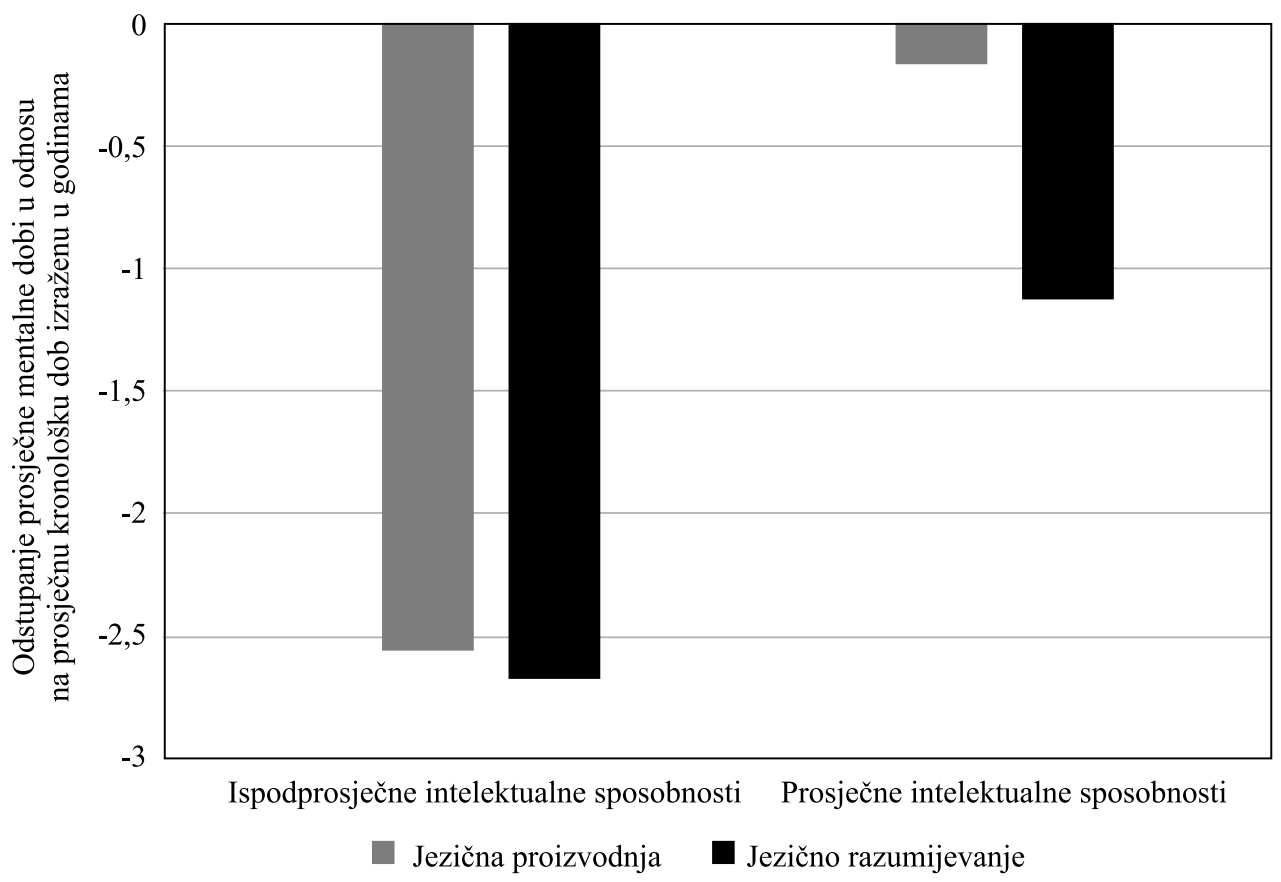

Slika 5. Prikaz razlika u sposobnostima jezične proizvodnje i razumijevanja djece sa PSAom s ispodprosječnim intelektualnim sposobnostima $(n=19)$ i s prosječnim intelektualnim sposobnostima $(n=6)$ s obzirom na odstupanja prosječne mentalne dobi postignute na podljestvicama RTČ-P-a u odnosu na prosječnu kronološku dob izraženu u godinama 
ni profil. Ako se uzmu u obzir ovakvi rezultati, ujednačenost jezične proizvodnje i razumijevanja kod djece s ispodprosječnim intelektualnim sposobnostima $(\mathrm{n}=19)$ i bolja jezična proizvodnja kod djece s prosječnim intelektualnim sposobnostima $(\mathrm{n}=6)$ u ovom istraživanju je očekivana (Slika 5).

$\mathrm{Na}$ rezultate utječe činjenica da ispitivanje jezičnog razumijevanja djece sa PSA-om može otežavati nekonzistentno odgovaranje i suradnja, a ispitivanje jezične proizvodnje eholalija i stereotipna jezična proizvodnja koja je učestala kod ove populacije (Hudry i sur., 2010); 60\% sudionika istraživanja na varijablama Jezična proizvodnja i Jezično razumijevanje nije uspjelo riješiti zadatke za dob od 2 godine (imenovanje dva predmeta na slici i pokazivanje nosa, usta i uha na sebi). Na sličan problem nailaze i Volden i sur. (2011) u svom istraživanju. Autori ističu teškoće provođenja bilo kojeg standardiziranog jezičnog instrumenta kod ove populacije te naglašavaju važnost temeljite analize (spontanih) jezičnih uzoraka. Smatraju da se samo na taj način može dobiti uvid u specifičnosti jezičnih sposobnosti djece sa PSA-om.

Teškoće procjene jezičnih sposobnosti djece rane i predškolske dobi sa PSA-om su gotovo neizbježne, a (ne)primjerenost mjernog instrumenta dodatno otežava uvid u njih. Test RTČ-P pokazuje nelogičnosti u redoslijedu, tj. očekivanim sposobnostima za pojedinu kronološku dob. Pritom po svojoj prirodi nije ciljano jezični test pa zadaci ne pokrivaju dovoljno sve jezične sastavnice potrebne za dobivanje realne slike odnosa jezične proizvodnje i razumijevanja.

U obzir treba uzeti ograničenja i nedostatke ovog istraživanja. Zbog teškoća i obilježja komunikacije i ponašanja djece sa PSA-om, često je bilo potrebno odstupiti od standardiziranog načina primjene mjernih instrumenata (ponavljanje naloga i sl.). Također, teško je generalizirati rezultate zbog malog uzorka $(n=25)$ unutar kojeg je heterogenost ove populacije dolazila još više do izražaja, što je općeniti nedostatak mnogih istraživanja djece sa PSA-om (Tager-Flusberg, 2004).

\section{ZAKLJUČAK}

Brojna strana istraživanja govore o neujednačenosti razvojnih profila djece sa PSA-om. Cilj ovog rada bio je stvoriti uvid u obilježja razvojnih profila djece sa PSA-om putem primjene Razvojnog testa Čuturić, koji se dominantno koristi u procjeni kognitivnih sposobnosti djece rane i predškolske dobi u Republici Hrvatskoj. Ovo istraživanje je utvrdilo da je neujednačenost razvojnog profila djece sa PSA-om moguće uočiti i na rezultatima testa RTČ-P. Očekivano, neujednačenost je uočena i kod djece s prosječnim i kod djece s ispodprosječnim intelektualnim sposobnostima. Promatrano na sveukupnom uzorku, pokazalo se kako su neverbalne sposobnosti na višoj razini od verbalnih sposobnosti. Ako sagledamo neverbalne sposobnosti, kao područje s najnižim postignućima se ističe grafomotorika, što govori u prilog stranoj literaturi. Kao područje s najvišim rezultatima istaknule su se vizuopercep- 
tivne sposobnosti. Neslaganja sa stranim istraživanjima koja ističu izrazito bolje vizuokonstruktivne sposobnosti pripisuju se razlikama u mjernim instrumentima (prije svega nejednaka složenost zadataka). Ako sagledamo verbalne sposobnosti, pokazalo se kako je jezična proizvodnja nešto bolja u odnosu na razumijevanje, što je također u skladu s pretpostavkom o atipičnosti jezičnih sposobnosti.

Sveukupno, rezultati na testu RTČ-P su pokazali neujednačenost razvojnog profila djece sa PSA-om, što je važan podatak zato što znanstvena literatura naglašava da je postojanje neujednačenog razvojnog profila osobitost djece sa PSA-om i važno je znati da je navedenu neujednačenost moguće uočiti i primjenom Razvojnog testa Čuturić (barem na razini grupe). Stoga je preporuka da stručnjaci, koji analizom rezultata Razvojnog testa Čuturić uoče nerazmjer u postignućima djeteta, razmotre i potrebu daljnje dijagnostike budući da je pojava ovog profila znatno češća u djece sa PSA-om.

Premda razvojni profili oblikovani kroz postignuća na testu RTČ-P ugrubo odgovaraju rezultatima stranih istraživanja, rezultati su ipak upozorili na potrebu stvaranja novih standardiziranih mjernih instrumenata za djecu rane i predškolske dobi koji bi pružili jasnije (detaljnije) analize sposobnosti u različitim razvojnim domenama. Sveukupno, maleni broj zadataka koji ispituju pojedino područje, ali i stupanj (ne)zahtjevnosti pojedinih zadataka ukazuju na potrebu postojanja obuhvatnijeg i suvremenijeg testa, kako za procjenu djece sa PSA-om, tako i općenito za svu djecu te dobi.

Razvojni profili su kod djece sa PSA-om posebno važni jer ističu njihovu specifičnu obradu informacija, koja ih razlikuje od ostalih skupina razvojnih poremećaja, a na temelju njih možemo zaključivati o djetetovim ,jakim“ i ,slabim“ stranama. Primjerice, bolje vizualne sposobnosti mogu se iskoristiti u intervenciji kroz potpomognutu komunikaciju i poticanje komunikacijskih i jezično-govornih sposobnosti kroz vizualni modalitet. U svrhu razvoja stručne podrške djeci sa PSA-om i njihovim obiteljima, potrebno je provesti još istraživanja o ovoj i sličnim temama. Bilo bi zanimljivo u profile uključiti i neke druge aspekte djetetova razvoja (primjerice, adaptivne vještine) koje određuju stupanj funkcioniranja djece sa PSA-om, ali i istu djecu ispitati u školskoj dobi kako bi se provjerilo postaju li razvojni profili sazrijevanjem sve ujednačeniji.

\section{LITERATURA}

Američka psihijatrijska udruga (2014.). Dijagnostički i statistički priručnik za duševne poremećaje, peto izdanje. Jastrebarsko: Naklada Slap.

ASHA (2012). ASHA's recommended revisions to the DSM-5. Preuzeto s http://www.asha. org/uploadedFiles/DSM-5-Final-Comments.pdf.

Ankenman, K., Elgin, J., Sullivan, K., Vincent, L. i Bernier, R. (2014). Nonverbal and verbal cognitive discrepancy profiles in autism spectrum disorders: Influence of age and gender. American Journal on Intellectual and Developmental Disabilities, 119, 84-99. 
Barbaro, J. i Dissanayake, C. (2012). Developmental profiles of children and toddlers with autism spectrum disorders identified prospectively in a community-based setting. Journal of Autism and Developmental Disorders, 42, 1939-1948.

Caron, M.J., Mottron, L., Berthiaume, C. i Dawson, M. (2006). Cognitive mechanisms, specificity and neural underpinnings of visuospatial peaks in autism. Brain, 129, 17891802.

Centers for Disease Control and Prevention (2014). Prevalence of autism spectrum disorder among children aged 8 years - Autism and Developmental Disabilities Monitoring Network, 11 Sites, United States, 2010. Morbidity and Mortality Weekly Report, 63, 1-21.

Chapman, N.H., Estes, A., Munson, J., Bernier, R., Webb, S.J., Rothstein, J.H., Minshew, N.J., Dawson, G., Schellenberg, G.D. i Wijsman, E.M. (2011). Genome-scan for IQ discrepancy in autism: evidence for loci on chromosomes 10 and 16. Human Genetics, 129, 59-70.

Čuturić, N. (1996). Priručnik za Razvojni test Čuturić. Jastrebarsko: Naklada Slap.

Dawson, M., Soulieres, I., Gernsbacher, M.A. i Mottron, L. (2007). The level and nature of autistic intelligence. Psychological Science, 18, 657-662.

Ellis Weismer, S., Lord, C. i Esler, A. (2010). Early language patterns of toddlers on the autism spectrum compared to toddlers with developmental delay. Journal of Autism and Developmental Disorders, 40, 1259-1273.

Happe, F. i Frith, U. (2006). The weak coherence account: Detail-focused cognitive style in autism spectrum disorders. Journal of Autism and Developmental Disorders, 36, 5-25.

Hudry, K., Leadbitter, K., Temple, K., Slonims, V., McConachie, H., Aldred, C., Howlink, P. i Charman, T. (2010). Preschoolers with autism show greater impairment in receptive compared with expressive language abilities. International Journal of Language and Communication Disorders, 45, 681-690.

Hudry, K., Chandler, S., Bedford, R., Pasco, G., Gliga, T., Elsabbagh, M., Johnson, M.H. i Charman, T. (2013). Early language profiles in infants at high-risk for autism spectrum disorders. Journal of Autism and Developmental Disorders, 44, 154-167.

Joseph, R.M., Tager-Flusberg, H. i Lord, C. (2002). Cognitive profiles and social-communicative functioning in children with autism spectrum disorder. Journal of Child Psychology and Psychiatry, 43, 807-821.

Kushki, A., Chau, T. i Anagnostou, E. (2011). Handwriting difficulties in children with autism spectrum disorders: A scoping review. Journal of Autism and Developmental Disorders, 41, 1706-1716.

Kwok, E.Y.L., Brown, H.M., Smyth, R.E. i Cardy, J.O. (2015). Meta-analysis of receptive and expressive language skills in autism spectrum disorders. Research in Autism Spectrum Disorders, 9, 202-222.

Luyster, R.J., Kadlec, M.B., Carter, A. i Tager-Flusberg, H. (2008). Language assessment and development in toddlers with autism spectrum disorders. Journal of Autism and Developmental Disorders, 38, 1426-1438.

Matson, J.L., Dempsey, T., LoVullo, S.V. i Wilkins, J. (2008). The effects of intellectual functioning on the range of core symptoms of autism spectrum disorders. Research in Developmental Disabilities, 29, 341-350.

Mayes, S.D. i Calhoun, S.L. (2003). Ability profiles in children with autism: Influence of age and IQ. Autism, 7, 65-80. 
Mayes, S.D. i Calhoun, S.L. (2008). WISC-IV and WIAT-II profiles in children with highfunctioning autism. Journal of Autism and Developmental Disorders, 38, 428-439.

Munson, J., Dawson, G., Sterling, L., Beauchaine, T., Zhou, A., Koehler, E., Lord, C., Rogers, S., Sigman, M., Estes, A. i Abbott, R. (2008). Evidence for latent classes of IQ in young children with autism spectrum disorder. American Journal of Mental Retardation, 113, 439-452.

Muth, A., Honekopp, J., Falter i C.M. (2014). Visuo-spatial performance in autism: A metaanalysis. Journal of Autism and Developmental Disorders, 44, 3245-3263.

Pierce, K., Marinero, S., Hazin, R., McKenna, B., Carter Banes, C. i Malige, A. (2016). Eye tracking reveals abnormal visual preference for geometric images as an early biomarker of an autism spectrum disorder subtype associated with increased symptom severity. Biological Psychiatry, 79, 657-666.

Rommelse, N., Langerak, I., van der Meer, J., de Bruijn, Y., Staal, W., Oerlemans, A. i Buitelaar, J. (2015). Intelligence may moderate the cognitive profile of patients with ASD. PLoS ONE, 10, 1-17.

Tager-Flusberg, H. (2004). Strategies for conducting research on language in autism. Journal of Autism and Developmental Disorders, 34, 75-80.

Thurm, A., Lord, C., Lee, L.C. i Newschaffer, C. (2007). Predictors of language acquisition in preschool children with autism spectrum disorders. Journal of Autism and Developmental Disorders, 37, 1721-1734.

Volden, J., Smith, I.M., Szatmari, P., Bryson, S., Fombonne, E., Mirenda, P., Roberts, W., Vaillancourt, T., Waddell, C., Zwaigenbaum, L., Georgiades, S., Duku, E. i Thompson, A. (2011). Using the preschool language scale, fourth edition to characterize language in preschoolers with autism spectrum disorders. American Journal of Speech-Language Pathology, 20, 200-208.

Wechsler, D. (1991). Wechsler intelligence scale for children - Third edition. San Antonio: Psychological Corporation.

Ziviani, J. i Wallen, M. (2006). The development of graphomotor skills. U Henderson, A. i Pehoski, C. (Ur.), Hand function in the child (Second edition) (str. 217-236). Philadelphia: Mosby Elsevier.

\title{
DEVELOPMENTAL PROFILES OF CHILDREN WITH AUTISM SPECTRUM DISORDER
}

\begin{abstract}
Summary
Research has shown that uneven developmental profiles, with better nonverbal than verbal abilities, are a common characteristic of children with Autism Spectrum Disorder (ASD). The aim of this research was to get an insight into the developmental profiles of the children with ASD on the Čuturić Developmental Test (RTČ-P), to describe their characteristics considering cognitive abilities and differences between developmental areas. The sample consisted of 25 children diagnosed with ASD. The
\end{abstract}


developmental profiles were based on scores achieved on the RTČ-P. As expected, children with ASD showed uneven developmental profiles. Both children with average $(n=6)$ and below average intellectual abilities $(n=19)$ showed uneven developmental profiles. In accordance with the expectation and other research, average nonverbal abilities scores were better than verbal abilities scores. The highest scores were achieved in visuo-perceptive abilities. With respect to verbal abilities, language expression scores were slightly higher than language comprehension scores, which is in accordance with the expected direction of unevenness in language skills. To conclude, developmental profiles are important in recognizing strengths and weaknesses in different abilities, which is crucial in creating interventions for children with ASD. They can also be useful in differential diagnostics of ASD and other developmental disabilities.

Key words: autism spectrum disorder, developmental profiles, Čuturić Developmental Test 
